(c) American Dairy Science Association, 2005.

\title{
Flavor and Stability of Pasteurized Milk with Elevated Levels of Conjugated Linoleic Acid and Vaccenic Acid*
}

\author{
J. M. Lynch, ${ }^{1}$ A. L. Lock, ${ }^{2}$ D. A. Dwyer, ${ }^{2}$ R. Noorbakhsh, ${ }^{3}$ D. M. Barbano, ${ }^{1}$ and D. E. Bauman ${ }^{2}$ \\ ${ }^{1}$ Department of Food Science, and \\ ${ }^{2}$ Department of Animal Science, Cornell University, Ithaca, NY 14853 \\ ${ }^{3}$ Institute of Standards and Industrial Research, Mashad, Iran
}

\begin{abstract}
The objectives of this study were to determine if flavor differences between $2 \%$ fat pasteurized milks with and without naturally enhanced vaccenic acid (VA) and cis9, trans-11 conjugated linoleic acids (CLA) levels could be detected over the commercial shelf life of the product and to determine if milk with elevated VA and cis-9, trans-11 CLA levels was more susceptible to development of light-induced oxidative flavor defects. Cows were fed a control diet or the same ration supplemented with $2 \%$ soybean oil and $1 \%$ fish oil (CLA diet). The milk, standardized to $2 \%$ fat, was pasteurized, homogenized, and stored in plastic containers at $4^{\circ} \mathrm{C}$. Oxidation was induced by exposing half of the containers to light. Testing was conducted at 1,7 , and $14 \mathrm{~d}$ postpasteurization. Average cis-9, trans-11 CLA content of the milks from the control and CLA diet groups was 0.52 and $4.74 \mathrm{~g} /$ $100 \mathrm{~g}$ of fatty acids, respectively (8-fold increase). Average VA content of the milk from the control and CLA diet groups was 1.43 and $12.06 \mathrm{~g} / 100 \mathrm{~g}$ of fatty acids, respectively (7.5-fold increase). Together, VA plus CLA represented almost $17 \%$ of the total milk fatty acids. There was no effect of light exposure on fatty acid composition initially or over the 14-d storage period. Although VA, cis-9, trans-11 CLA, and degree of unsaturation were significantly elevated in the milk from the CLA diet group, untrained panelists were unable to detect flavor differences initially or over time in 15 of 16 triangle test evaluations. Similarly, sensory results indicated no difference in susceptibility to the development of oxidized off-flavors between the milk from the
\end{abstract}

Received June 6, 2004.

Accepted August 4, 2004.

Corresponding author: Joanna M. Lynch; e-mail: JL72@ cornell.edu.

*Use of names, names of ingredients, and identification of specific models of equipment is for scientific clarity and does not constitute any endorsement of product by authors, Cornell University, the Institute of Standards and Industrial Research, or the Northeast Dairy Foods Research Center. control and CLA diet groups, even when oxidation was induced by light exposure.

(Key words: conjugated linoleic acid, milk flavor, oxidation, vaccenic acid)

Abbreviation key: CLA = conjugated linoleic acid, $\mathbf{C N} \% \mathbf{C P}=$ casein as a percentage of crude protein, $\mathbf{F O}=$ fish oil, VA = vaccenic acid.

\section{INTRODUCTION}

Dairy products are the major source of conjugated linoleic acids (CLA) in US diets (60 to $70 \%$; Ritzenthaler et al., 2001) and the major CLA isomer in milk fat is cis-9, trans-11 CLA (75 to 90\%; Bauman et al., 2003). Biomedical studies using animal models have identified many beneficial health effects of CLA. In particular, the cis-9, trans-11 CLA isomer has been identified as a potent anticarcinogen for many types of cancer (Belury, 2002; Banni et al., 2003) and it has been shown to prevent development and cause regression of atherosclerotic lesions in animal models for coronary heart disease (Kritchevsky, 2003; Toomey et al., 2003). Consequently, surveys indicate a consumer interest in food products that are enriched in CLA (Ramaswamy et al., 2001a).

A portion of the cis-9, trans-11 CLA in ruminant fat originates from incomplete rumen biohydrogenation of linoleic acid. However, the major source is from endogenous synthesis involving the enzyme $\Delta^{9}$-desaturase, with the substrate being vaccenic acid (VA; trans- 11 18:1) that is produced as an intermediate during rumen biohydrogenation (Bauman et al., 2003). Other species, including humans, have $\Delta^{9}$-desaturase so they can also synthesize cis-9, trans-11 CLA endogenously using VA consumed in the diet. Because of the unique precursorproduct relationship between VA and cis-9, trans-11 CLA in dairy cows, efforts to increase cis-9, trans-11 CLA result in a concomitant increase in the milk fat content of VA. Based on the typical relationship between these fatty acids in milk fat and the extent of VA conversion to cis-9, trans-11 CLA in humans (Turpeinen et al., 2002), Parodi (2003) has suggested that multiplying the amount of cis-9, trans-11 CLA by 1.4 
provides an estimate of the effective physiological dose of cis-9, trans-11 CLA in foods derived from ruminants.

Diet has a major effect on the milk fat content of CLA, presumably related to effects on rumen production of VA (Bauman et al., 2003; Stanton et al., 2003). In addition, there is substantial variation among cows fed the same diet and this likely relates in large part to individual differences in $\Delta^{9}$-desaturase (Bauman et al., 2003). In general, storage and processing have little effect on the CLA content of milk fat, so the content in dairy products is essentially dependent on the CLA content of the starting milk fat (Shantha et al., 1995; Parodi, 2003). Reports on sensory characteristics and quality of dairy products containing elevated CLA, typically 2to 3-fold increases, have generally indicated no adverse effects (Baer et al., 2001; Ramaswamy et al., 2001a, b; Avramis et al., 2003; Gonzalez et al., 2003), although there are exceptions (Lacasse et al., 2002). Off-flavors due to fatty acid oxidation are of prime concern because of the shift toward greater unsaturation of the milk fat.

Objectives of the present study were to evaluate flavor differences over the commercial shelf life of $2 \%$ fat pasteurized milks with and without naturally enhanced VA and CLA content, and to determine if there were differences in susceptibility to light-induced oxidative flavor defects. By manipulating the diet and selecting cows with a high milk CLA content, we were able to attain a milk fat that had $>16 \%$ of total fatty acids as VA plus CLA.

\section{MATERIALS AND METHODS}

\section{Milk Production}

The Cornell University Institutional Animal Care and Use Committee approved all procedures involving animals. Sixteen multiparous Holstein cows with low SCC located at the Cornell University Teaching and Research Center were used. One group of cows $(n=6)$ was fed a corn-based TMR to produce control milk fat (control diet) and a second group of cows $(\mathrm{n}=10)$ was fed the same TMR supplemented with $2 \%$ soybean oil and $1 \%$ fish oil (FO) to produce a milk fat that was enriched with VA and cis-9, trans-11 CLA (CLA diet). After $1 \mathrm{wk}$ of consuming the CLA diet, milk samples were obtained and the cis-9, trans-11 CLA content of the milk fat was determined. Subsequently, milk was collected from the 6 cows in the CLA diet group with the highest milk fat content of cis-9, trans-11 CLA and all 6 cows from the control group; milk was collected on 3 separate occasions over a 2 -wk period.

\section{Milk Processing}

On the day of milk collection, all the milk from one milking was collected separately from each cow, imme- diately transported to Cornell Food Science Department Pilot Plant and rapidly cooled on ice to $4^{\circ} \mathrm{C}$. Samples of the milk from each cow were taken, preserved with bronopol tablets (Preservative System Limited, San Francisco, CA) and tested for SCC (AOAC, 2000; method number 17.13.01, 978.26) and true protein (AOAC, 2000; method number 33.2.31, 972.16). Milks from cows with acceptable SCC $(<200,000$ cells $/ \mathrm{mL})$ were pooled by treatment group in amounts designed to balance the true protein content between groups.

Each commingled milk was heated and separated at $49^{\circ} \mathrm{C}$ into skim and cream using a cream separator (model 102; DeLaval, Stockholm, Sweden) and cooled to $4^{\circ} \mathrm{C}$. The fat contents of the skim (Marshall, 1993; method number 15.8B) and cream (AOAC, 2000; method number 33.3.18, 995.18) were determined by the Babcock method. The next day, the skim and cream were combined to a target fat content of $2 \%$. The $2 \%$ standardized milk was homogenized (first stage 13.8 $\mathrm{MPa}$, second stage $3.5 \mathrm{MPa}$ ) at $60^{\circ} \mathrm{C}$ (model $200 \mathrm{E}$, Gaulin, Everett, MA), immediately pasteurized (HTST, $76^{\circ} \mathrm{C} / 30 \mathrm{~s}$ ) in shell and tube pasteurizer, and cooled to $4^{\circ} \mathrm{C}$. Pasteurization was confirmed by the phosphatase test (Charm Pas Lite method; Charm Science Inc., Malden, MA). The pasteurized, homogenized $2 \%$ milk was portioned into 2-L high-density polyethylene plastic containers obtained from a local dairy plant. The containers were stored in the dark at $4^{\circ} \mathrm{C}$ for the duration of the study.

\section{Light Exposure}

Immediately after processing, half of the containers of processed milk for each diet group were exposed to 2 fluorescent lamps with wavelengths of 400 to $700 \mathrm{~nm}$ in a light box located inside a $4^{\circ} \mathrm{C}$ walk-in cooler. The containers were placed parallel to the light bulbs to achieve a light intensity of $2000 \mathrm{~lx} \pm 5 \%$ at the nearest exposed container surface. This exposure was chosen to approximate the median light intensity typical of retail dairy cases (Chapman et al., 2002). Light intensity was measured with a digital light meter (Dickson \#D102, Universal Enterprises Inc., Beaverton, OR). The containers were exposed to the light for $2 \mathrm{~h}$. Although fluid milk products packaged in plastic containers will typically remain under lights in commercial dairy cases for longer, the period of $2 \mathrm{~h}$ was selected so that oxidized flavor would be produced but not be overwhelming. Untrained consumers can detect lightoxidized flavors in reduced fat milk after the milk has been exposed to $2000 \mathrm{~lx}$ for 1 to $2 \mathrm{~h}$ (Chapman et al., 2002). 


\section{Storage, Sampling, and Replication}

After processing and light treatment, all containers of processed milk were stored in the dark at $4^{\circ} \mathrm{C}$ for the duration of the study. Analysis and testing were conducted at 1, 7, and $14 \mathrm{~d}$ postpasteurization. The entire process of milk collection, processing, and testing was replicated 3 times ( 3 trials).

\section{Chemical and Microbiological Analyses}

Initial milk composition. The initial composition of the $2 \%$ pasteurized, homogenized milks from the treatment groups with or without light exposure was determined on d 1 postpasteurization. All analyses were conducted in duplicate. Milk was tested for SCC using a Fossomatic cell counter (AOAC, 2000; method number 17.13.01, 978.26), fat by Mojonnier ether extraction (AOAC, 2000; method number 33.2.26, 989.05) and total solids by forced air oven drying (AOAC, 2000; method number 33.2.44, 990.20). Kjeldahl nitrogen analysis was used to determine crude protein nitrogen (AOAC, 2000; method number 33.2.11, 991.20), noncasein nitrogen (AOAC, 2000; method number 33.2.64, 998.05), and nonprotein nitrogen (AOAC, 2000; method number 33.2.12, 991.21). All Kjeldahl nitrogen results were expressed on a protein basis $(\mathrm{N} \times 6.38)$. True protein was calculated as the difference between crude protein and nonprotein nitrogen $(\times 6.38)$, and casein was calculated as the difference between crude protein and noncasein nitrogen $(\times 6.38)$.

Milk composition over shelf life. Milk proteolysis, microbiological quality, and fatty acid composition were determined on $\mathrm{d} 1,7$, and 14 postpasteurization. Proteolysis was determined by measuring casein using Kjeldahl analysis as previously described. The decrease in casein as a percentage of the crude protein $(\mathbf{C N} \% \mathbf{C P})$ was used as an index of proteolysis. Microbiological quality was monitored at the stated intervals and more frequently as needed, using standard plate count (Marshall, 1993; method number 6.2) and coliform count (Marshall, 1993; method number 7.8).

Fatty acid analysis. Milk fat was extracted using the method of Hara and Radin (1978). Fatty acid methyl esters from milk fat extracts were prepared by basecatalyzed transmethylation according to Christie (1982) with modifications by Chouinard et al. (1999). Fatty acid methyl esters were analyzed by gas chromatography (Hewlett Packard GC system 6890+ with flame ionization detector) using a CP-Sil 88 capillary column $(100 \mathrm{~m} \times 0.25 \mathrm{~mm}$ i.d., $0.2 \mu \mathrm{m}$ film thickness; Varian Inc., Walnut Creek, CA) according to the methods described by Lock et al. (2004). Fatty acid peaks were identified using pure methyl ester standards (NuChek Prep, Elysian, MN). A butter oil reference stan- dard (CRM 164; Commission of the European Community Bureau of References, Brussels, Belgium) and the pure standards were used to determine recoveries and correction factors for individual fatty acids. In practice, recovery correction factors were needed only for the very short chain fatty acids.

\section{Sensory Evaluation}

A variety of fat levels and processing conditions were used in previous various research reports. Baer et al. (2001) and Ramaswamy et al. (2001a, b) used unstandardized milk with fat contents of $3 \%$ (control) and 2.4 to $2.6 \%$ (FO diet). The milk was batch pasteurized (Baer et al., 2001; Ramaswamy et al., 2001b), or HTST pasteurized and homogenized (Ramaswamy et al., 2001a). Lacasse et al. (2002) used milk standardized to $2.7 \%$ and pasteurized (conditions not reported). Avramis et al. (2003) standardized to $2 \%$ fat and UHT pasteurized, and Campbell et al. (2003) standardized to $2 \%$ followed by HTST pasteurization and homogenization. In the present study, the milk was standardized to $2 \%$, HTSTpasteurized, and homogenized, which represents typical processing conditions in the United States. Per capita sales of whole milk ( $3.25 \%$ fat) have declined from $58.8 \%$ in 1980 to 33\% of fluid milk sales in 2002 (International Dairy Foods Association, 2003). Per capita sales of low fat (1\%) and reduced fat (2\%) milk combined were $43.5 \%$ of total per capita sales of fluid milk in 2002 (International Dairy Foods Association, 2003) resulting in an average fat content of fluid milk consumed in the United States of between 1 and 2\%. Thus, we elected to standardize to $2 \%$ fat because it would be close to the average composition of fluid milk consumed in the United States. If there were a large impact of CLA or related fatty acids on milk flavor, it would be expected to be detectable in milk containing 2 or $3.25 \%$ fat.

Sensory evaluation was conducted on d 1,7 , and 14 postpasteurization using triangle tests (O'Mahony, 1986). For each triangle test, subjects were given 3 milk samples to taste. Two of the samples were the same and one was different. Subjects were asked to identify the sample that differed from the other 2. Selection of the odd sample constituted a correct choice.

Twenty-four untrained panelists were recruited from the Cornell University community on each testing day to take 2 triangle tests. In the first test, subjects compared the milk from the control and CLA diets that had not been exposed to light ("dark" exposure) and in the second test they compared the milks from the control and CLA diets that had been exposed to light ("light" exposure). For each triangle test, samples were randomly coded and the order of administration was selected using a balanced randomized design. To mini- 
mize the possibility of the carryover of strong flavors, the triangle test using the dark exposure group was always given first. The milk samples were tasted at $6^{\circ} \mathrm{C}$, and water and crackers were available to the subjects to cleanse their palates. The use of human subjects in this study was reviewed and approved by the Cornell University Committee on Human Subjects.

\section{Statistics}

Data from the triangle tests were analyzed using a binomial probability model at a significance level of $P$ $<0.05$. The power of the test was set at 0.90 if $50 \%$ of the panelists were able to detect a difference between the milk samples (probability of a correct identification $=0.667$ ). Using these criteria, at least 13 of 24 panelists had to correctly identify the odd sample to conclude that there was a significant difference between the 2 milks being compared.

Data for fatty acid composition and $\mathrm{CN} \% \mathrm{CP}$ were analyzed using the GLM procedure of SAS (Version 8e, 2001, SAS Institute, Inc., Cary, NC) using a split-plot model, with terms for diet, trial, light exposure, all 2way, and the 3-way interaction of these terms in the whole plot, and day postpasteurization and all 2-way and 3-way interaction terms in the subplot. The 3-way interaction of diet, trial, and light exposure was used as the error term for the test of significance of terms in the whole plot. Because day postpasteurization was treated as a continuous variable in the ANOVA model, distortion of the ANOVA by multicollinearity of terms in the model was minimized by centering the time variable using a mathematical transformation (Glantz and Slinker, 2001). The time was transformed as follows: time = day postpasteurization $-[$ (last day postpasteurization - day postpasteurization) / 2]. This transformation made the data set orthogonal with respect to time postpasteurization. This transformation directs SAS to determine the main effects of diet, trial, and light exposure in the whole plot at the midpoint of time postpasteurization instead of $\mathrm{d} 1$. If the $F$-test of the model was significant $(P<0.05)$, then least square means for diet, trial, and exposure were tested $(P<0.01)$ using the diet $\times$ trial $\times$ exposure as the error term. The model error was used to test for significance of variables $(P<0.01)$ in the split-plot. Interaction terms within the spilt-plot that were not significant $(P>0.01)$ were removed from the model one at a time starting with the term that had the lowest Type III sum of squares, until all nonsignificant terms were removed from the split-plot. Next, a step-wise removal of all nonsignificant interaction terms from the whole plot was done. Percentage of the total variation explained by remaining individual terms in the model that were significant was calculated using the Type III sum of squares for the individual term divided by the total Type III sum of squares for the model.

\section{RESULTS}

\section{Fatty Acid Composition}

The milk fatty acid profiles for the control and CLA diet groups were determined on d 1, 7, and 14 postpasteurization (Table 1). The effect of exposure (light or dark) on individual fatty acids was not significant in any of the statistical analyses and the data represent an average of the 3 trials and both exposures. Results of the statistical analysis are presented as a percentage of the Type III sum of squares of the model variance, illustrating the amount of variation accounted for by the main effects and interactions. Effects of exposure and 3-way interactions were not statistically significant and are not shown. As expected, the effect of diet on the individual fatty acids was significant for nearly all fatty acids $(P<0.01)$; diet accounted for over $95 \%$ of the model variance in most cases. The effects of trial and day accounted for only a small portion of the variance for most fatty acids. A summary of the effect of diet on mean fatty acid composition is presented in Table 2.

\section{Milk Composition and Sensory Evaluation}

The starting milks for each trial had a similar composition for the control and CLA diet groups (Table 3). Over the 14-d shelf life, CN\%CP decreased in both diet groups, with the day effect $(P<0.01)$ accounting for $70 \%$ of the model variance (Table 4). Compared with initial levels, CN\%CP decreased by $2.06 \%$ in the control diet group and $2.19 \%$ in the CLA diet group by $\mathrm{d} 14$. The effect of light exposure was not significant.

Results from the sensory evaluation using triangle tests conducted on $\mathrm{d} 1,7$, and 14 postpasteurization are presented in Table 5. Panelists could not detect a difference in flavor between milks regardless of dietary treatment, day, or light exposure in 15 of 16 sets of triangle tests. A significant difference in flavor between the control and CLA diet milks was identified only in the light-exposed group on d 14 of trial 2.

\section{DISCUSSION}

\section{Fatty Acid Composition}

Diet can markedly affect the fatty acid composition of milk fat, and the treatment differences in fatty acid profile in the present study are typical of the pattern of response to dietary manipulation designed to increase 
Table 1. Mean fatty acid composition of milk fat from the control and CLA diet groups at d 1, 7, and 14 postpasteurization. ${ }^{1}$

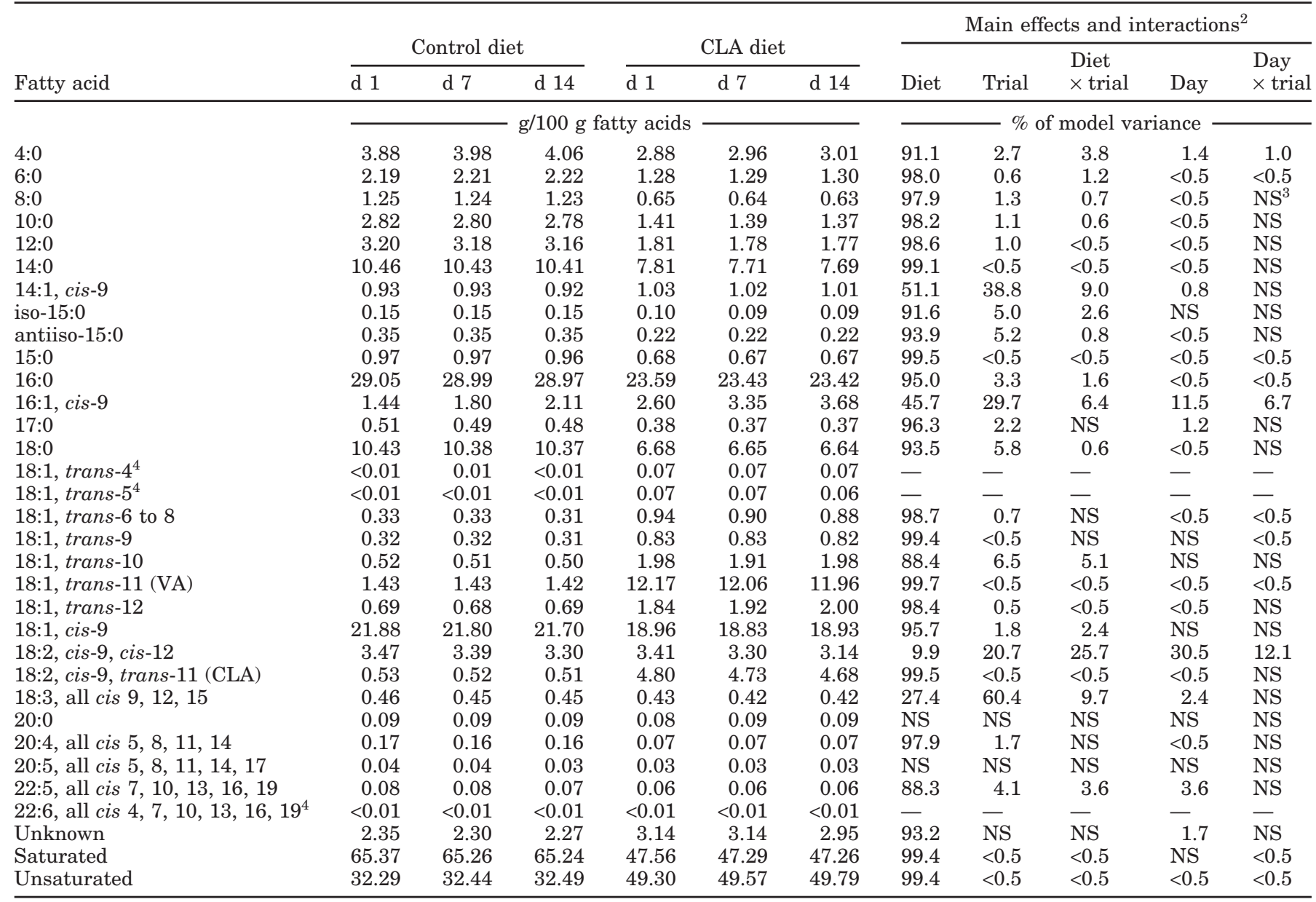

${ }^{1}$ Mean for each day represents the average of the dark and light exposure treatments for each of 3 trials.

${ }^{2} P<0.01$ unless otherwise indicated.

${ }^{3} \mathrm{NS}=$ Not significant at $\alpha=0.01$.

${ }^{4}$ Statistical analysis not carried out because of fatty acid levels $<0.01 \mathrm{~g} / 100 \mathrm{~g}$ of fatty acids.

CLA levels (Chouinard et al., 2001; Stanton et al., 2003; Lock and Shingfield, 2004). Milk fat from the CLA diet group had a decrease in the percentage of de novo fatty acids and an increase in the long-chain fatty acids compared with milk fat from the control diet, as well as a marked increase in the degree of unsaturation (Tables 1 and 2). Diet is the major factor affecting the CLA content of milk fat, but there is also a 3 -fold difference among individuals on the same diet (Bauman et al., 2003; Kelsey et al., 2003). By using a combination of diet and selection of individuals with a high CLA content, we achieved a VA + CLA content $>16 \%$ of total fatty acids, much larger than that typically achieved in sensory research (Baer et al., 2001; Ramaswamy et al., 2001a, b; Lacasse et al., 2002; Gonzalez et al., 2003). The average cis-9, trans-11 CLA content of the control and VA/ CLA-enriched milks was 0.52 and $4.74 \mathrm{~g} / 100 \mathrm{~g}$ of fatty acids, respectively, representing an 8-fold increase (Ta- ble 2). For VA, the average content of the control and VA/CLA-enriched milks was 1.43 and $12.06 \mathrm{~g} / 100 \mathrm{~g}$ of fatty acids, respectively, for a 7.5-fold increase (Table 2). In humans, VA contributes to the total available CLA because of endogenous conversion of dietary VA to cis9, trans-11 CLA. Using $1.4 \times$ milk cis-9, trans- 11 CLA to estimate the effective physiological dose of cis-9, trans-11 CLA in foods derived from dairy products (Parodi, 2003), the control and milk from the CLA diet group in the current study provided a physiological equivalent to 0.73 and $6.6 \mathrm{~g} / 100 \mathrm{~g}$ of fatty acids, respectively. For milk from the CLA diet group, the CLA contribution to total dietary CLA would be significant, even though the amount of dietary CLA needed to elicit beneficial health effects remains speculative. An early estimate, extrapolated from animal models, was $3 \mathrm{~g}$ of CLA/d for a 70$\mathrm{kg}$ human (Ip et al., 1994). More recent estimates (that take into account human metabolic rate) are in the 
LYNCH ET AL.

Table 2. Comparison of the mean fatty acid composition of milk fat from the control and CLA diet groups.

\begin{tabular}{|c|c|c|c|c|}
\hline \multirow[b]{2}{*}{ Fatty acid } & \multicolumn{2}{|c|}{ Diet group mean ${ }^{1}$} & \multirow[b]{2}{*}{$\mathrm{SEM}^{2}$} & \multirow{2}{*}{$\begin{array}{l}\text { Change } \\
\text { from } \\
\text { control }\end{array}$} \\
\hline & Control & CLA & & \\
\hline & \multicolumn{3}{|c|}{$-\mathrm{g} / 100 \mathrm{~g}$ of fatty acids -} & $(\%)$ \\
\hline $4: 0$ & 3.97 & 2.95 & 0.0101 & -26 \\
\hline $6: 0$ & 2.21 & 1.30 & 0.0031 & -42 \\
\hline $8: 0$ & 1.24 & 0.64 & 0.0026 & -48 \\
\hline $10: 0$ & 2.80 & 1.39 & 0.0041 & -50 \\
\hline $12: 0$ & 3.18 & 1.79 & 0.0037 & -44 \\
\hline $14: 0$ & 10.44 & 7.73 & 0.0140 & -26 \\
\hline $14: 1$, cis -9 & 0.93 & 1.02 & 0.0017 & 10 \\
\hline iso- $15: 0$ & 0.15 & 0.09 & 0.0009 & -40 \\
\hline antiiso-15:0 & 0.35 & 0.22 & 0.0009 & -37 \\
\hline $15: 0$ & 0.97 & 0.67 & 0.0019 & -31 \\
\hline $16: 0$ & 29.00 & 23.48 & 0.0281 & -19 \\
\hline $16: 1$, cis -9 & 1.78 & 3.21 & 0.0942 & 80 \\
\hline $17: 0$ & 0.49 & 0.37 & 0.0022 & -24 \\
\hline $18: 0$ & 10.39 & 6.66 & 0.0107 & -36 \\
\hline $18: 1$, trans $-4^{3}$ & $\ldots$ & $\ldots$ & $\ldots$ & $\ldots$ \\
\hline $18: 1$, trans $-5^{3}$ & $\cdots$ & $\cdots$ & $\cdots$ & $\cdots$ \\
\hline $18: 1$, trans -6 to 8 & 0.32 & 0.91 & 0.0043 & 184 \\
\hline $18: 1$, trans -9 & 0.31 & 0.83 & 0.0175 & 168 \\
\hline $18: 1$, trans -10 & 0.51 & 1.96 & 0.0178 & 284 \\
\hline $18: 1$, trans-11 (VA) & 1.43 & 12.06 & 0.0152 & 743 \\
\hline $18: 1$, trans -12 & 0.69 & 1.92 & 0.0125 & 178 \\
\hline $18: 1$, cis -9 & 21.79 & 18.91 & 0.0242 & -13 \\
\hline $18: 2$, cis -9, cis- 12 & 3.38 & 3.28 & 0.0193 & -3 \\
\hline $18: 2$, cis -9, trans -11 (CLA) & 0.52 & 4.74 & 0.0127 & 812 \\
\hline $18: 3$, all cis $9,12,15$ & 0.45 & 0.42 & 0.0011 & -7 \\
\hline $20: 0$ & 0.09 & 0.09 & $0.0022^{4}$ & 0 \\
\hline $20: 4$, all cis $5,8,11,14$ & 0.16 & 0.07 & 0.0011 & -56 \\
\hline $20: 5$, all cis $5,8,11,14,17$ & 0.03 & 0.03 & 0.0015 & 0 \\
\hline $22: 5$, all cis $7,10,13,16,19$ & 0.08 & 0.06 & $0.0006^{4}$ & -25 \\
\hline $22: 6$, all cis $4,7,10,13,16,19^{3}$ & $\ldots$ & & & \\
\hline Unknown & 2.31 & 3.08 & 0.0204 & 33 \\
\hline Saturated & 65.29 & 47.37 & 0.0469 & -27 \\
\hline Unsaturated & 32.40 & 49.55 & 0.0474 & 53 \\
\hline
\end{tabular}

\footnotetext{
${ }^{1}$ Mean for each diet group represents the average of $d 1,7$, and 14 postpasteurization for both the dark and light exposure treatments for each of the 3 trials.

${ }^{2} P<0.01$ unless otherwise indicated.

${ }^{3}$ Statistical analysis not carried out because of fatty acid levels $<0.01 \mathrm{~g} / 100 \mathrm{~g}$ of fatty acids.

${ }^{4}$ Not significant at $\alpha=0.01$.
}

order of 0.7 to $0.8 \mathrm{~g}$ of CLA/d (Parrish et al., 2003; Watkins and Li, 2003). Between 2 to 3 cups (474 to 711 $\mathrm{mL}$ ) of $2 \%$ milk (or 1.5 to 2.5 cups of whole milk, $3.25 \%$ fat) with VA and cis-9, trans-11 CLA content similar to that achieved in this study would supply this amount, independently of other dietary sources of CLA. It must be noted that in animal models of cancer, a massive dose of carcinogen is given so that experimentally $100 \%$ of the animals would have large numbers of tumors in a short time (Bauman et al., 2000). Consequently, to examine anticancer effects in these models, large doses of anticarcinogen are required and extrapolation from these doses would tend to be an overestimation of the actual requirement. The fact that VA can be converted to cis-9, trans-11 CLA differentiates this isomer from other trans fatty acids, and some of the broader implications of this for the new regulations in nutritional label- ing have been discussed elsewhere (Bauman et al., 2004).

The fatty acid profile of the milks from the control and CLA diet groups was determined at $\mathrm{d} 1,7$, and 14 postpasteurization (Table 1). Although statistically significant differences were found for many of the fatty acids for the effect of day and day $\times$ trial interaction, the absolute differences were minor and within the range of normal analytical variation. This is in agreement with previous research indicating that the effects of processing or storage were absent or very small and of little practical significance (Shantha et al., 1995; Parodi, 2003). Of note is that the $\mathrm{n}-3$ fatty acids $(20: 5,22: 6)$ were not significantly elevated in the CLA diet group, despite the inclusion of $1 \% \mathrm{FO}$ in the diet.

There was no effect of light exposure on fatty acid composition initially or over the 14-d storage period. 
Table 3. Composition of pasteurized milk from control and conjugated linoleic acids-enhanced (CLA) diet groups by trial.

\begin{tabular}{llllllll}
\hline & & \multicolumn{5}{c}{ Milk component, g/100 g } \\
\cline { 3 - 7 } Trial & Diet & Fat & $\begin{array}{l}\text { Crude } \\
\text { protein }\end{array}$ & $\begin{array}{l}\text { True } \\
\text { protein }\end{array}$ & Casein & $\begin{array}{l}\text { NPN } \\
(\times 6.38)\end{array}$ & $\begin{array}{l}\text { Total } \\
\text { solids }\end{array}$ \\
\hline 1 & Control & 1.95 & 3.23 & 3.03 & 2.52 & 0.20 & 10.85 \\
& CLA & 2.04 & 3.18 & 3.00 & 2.47 & 0.19 & 10.76 \\
2 & Control & 2.00 & 3.12 & 2.92 & 2.44 & 0.20 & 10.82 \\
& CLA & 2.03 & 3.07 & 2.88 & 2.38 & 0.19 & 10.53 \\
3 & Control & 1.98 & 3.21 & 3.01 & 2.50 & 0.20 & 10.86 \\
& CLA & 2.08 & 3.12 & 2.93 & 2.41 & 0.19 & 10.78 \\
\hline
\end{tabular}

A lack of effect on milk fatty acid composition due to oxidation induced by sunlight or added copper in milk with elevated VA and cis-9, trans-11 CLA levels has been previously reported (Baer et al., 2001).

\section{Milk Composition and Sensory Evaluation}

The percentages of fat, protein, and total solids in milk from the control and CLA diet groups were similar (Table 3). The initial CN\%CP was slightly lower for the CLA diet (77.45\%) compared with the control diet (77.89\%) groups, which we attribute to normal variation between the 2 groups of cows (Table 4). Casein breakdown is associated with the development of bitter off-flavors (Ma et al., 2000). Casein degradation over time, as evidenced by the decrease in $\mathrm{CN} \% \mathrm{CP}$, was similar in milk from the control and CLA diet groups and was not affected by light exposure. The rate of breakdown over the 14-d shelf life for both milks was typical (2.06 and $2.19 \mathrm{CN} \%$ of true protein) of that observed for pasteurized milk stored at $4^{\circ} \mathrm{C}$ (Santos et al., 2003).

Although the levels of VA, cis-9, trans-11 CLA and degree of unsaturation were significantly elevated in the milk from the CLA diet group, untrained panelists were unable to detect flavor differences between the control diet and CLA diet group milks in 15 of 16 taste test evaluations (Table 5). With 16 sets of triangle tests run, each with a significance level of $0.05 \%$, there is a high degree of probability ( $55 \%$ if all tests were independent) that at least one will be identified as statistically significant by chance alone. Overall, the sensory evaluations indicate that panelists found no flavor differences (power $=90 \%$ ) between milks from the control and CLA diet groups over the 14-d shelf life. Similarly, there was no difference in susceptibility to the development of oxidized off-flavors between the 2 types of milk, even when oxidation was induced by light exposure (Table 5).

Most research on the sensory characteristics and quality indicators of dairy products produced from milk with elevated CLA content supports this conclusion. Baer et al. (2001) used milk from cows supplemented with $2 \% \mathrm{FO}$ to evaluate the properties of pasteurized milk, particularly with regard to oxidative susceptibility. Compared with the control, VA and CLA in the milk fat from the FO group were elevated 2.7- and 3.4-fold, respectively. Trained panelists eval-

Table 4. Casein as a percentage of crude protein (CN\%CP) by diet group, day postpasteurization (PP), and trial.

\begin{tabular}{|c|c|c|c|c|c|c|c|c|c|c|c|}
\hline \multirow[b]{3}{*}{ Trial } & \multicolumn{4}{|c|}{ Control diet } & \multicolumn{4}{|c|}{ CLA diet } & & & \\
\hline & \multicolumn{3}{|c|}{ Day PP } & \multirow[b]{2}{*}{$\mathrm{d} 1-\mathrm{d} 14^{1}$} & \multicolumn{3}{|c|}{ Day PP } & \multirow[b]{2}{*}{ d $1-$ d 14} & \multicolumn{3}{|c|}{ Main effects ${ }^{2}$} \\
\hline & 1 & 7 & 14 & & 1 & 7 & 14 & & Diet & Trial & Day \\
\hline & & & & $\mathrm{CN}^{\mathrm{C}}$ & $\mathrm{CP}$ & & & 4 & $\%$ of & nodel v & ariance \\
\hline 1 & 77.94 & 77.41 & 75.28 & 2.66 & 77.50 & 76.39 & 75.36 & 2.14 & & & \\
\hline 2 & 78.09 & 77.68 & 76.90 & 1.18 & 77.71 & 76.47 & 75.68 & 2.03 & & & \\
\hline 3 & 77.66 & 76.76 & 75.33 & 2.32 & 77.13 & 76.02 & 74.73 & 2.40 & & & \\
\hline Mean & 77.89 & 77.28 & 75.84 & 2.06 & 77.45 & 76.30 & 75.26 & 2.19 & $\mathrm{NS}^{3}$ & NS & $70.00^{4}$ \\
\hline
\end{tabular}

${ }^{1} \mathrm{~d} 1-\mathrm{d} 14$ = Difference in CN\%CP at d 1 and 14 postpasteurization.

${ }^{2}$ Standard errors of the means were $0.1281,0.1568$, and $0.1572 \%$ for the effects of diet, trial, and day, respectively.

${ }^{3} \mathrm{NS}=$ Not significant at $\alpha=0.01$.

${ }^{4} P<0.01$. 
Table 5. Sensory analysis with and without light exposure using triangle tests at $\mathrm{d} 1,7$, and 14 postpasteurization.

\begin{tabular}{|c|c|c|c|c|}
\hline \multirow[b]{2}{*}{ Trial } & \multirow[b]{2}{*}{ Exposure $^{1}$} & \multicolumn{3}{|c|}{ Day postpasteurization } \\
\hline & & 1 & 7 & 14 \\
\hline & & \multicolumn{3}{|c|}{ - Correct responses/number of panelists - } \\
\hline 1 & $\begin{array}{l}\text { Dark } \\
\text { Light }\end{array}$ & $\begin{array}{l}11 / 24 \\
10 / 24\end{array}$ & $\begin{array}{r}12 / 24 \\
9 / 24\end{array}$ & $\begin{array}{l}10 / 24 \\
11 / 24\end{array}$ \\
\hline 2 & $\begin{array}{l}\text { Dark } \\
\text { Light }\end{array}$ & $\begin{array}{l}9 / 24 \\
9 / 24\end{array}$ & $\begin{array}{l}10 / 24 \\
12 / 24\end{array}$ & $\begin{array}{c}9 / 24 \\
15 / 24^{2}\end{array}$ \\
\hline 3 & $\begin{array}{l}\text { Dark } \\
\text { Light }\end{array}$ & $\begin{array}{l}11 / 24 \\
10 / 24\end{array}$ & $\begin{array}{r}6 / 24 \\
12 / 24 \\
\end{array}$ & $-^{3}$ \\
\hline
\end{tabular}

${ }^{1}$ Milk was exposed to 2 fluorescent lamps for $2 \mathrm{~h}$ at $2000 \mathrm{~lx}$ (light) or not exposed (dark).

${ }^{2}$ Significant at $\alpha=0.05$ (correct responses for $\geq 13$ panelists out of a total of 24 panelists).

${ }^{3}$ Sensory analysis not conducted because of microbial spoilage of the milk in both exposure groups.

uated oxidation in the pasteurized milk with and without the addition of copper. No difference in oxidative flavor was noted at d 2 or 6 postpasteurization for milks without added copper. For milks with added copper, oxidative flavor was more pronounced at $\mathrm{d} 2$ postpasteurization in the FO milk but not different from the control at $d 6$. The same research group ( $\mathrm{Ra}$ maswamy et al., 2001b) did further work on the composition and flavor of milk and butter, using milk from cows fed FO ( $2 \% \mathrm{DM})$, extruded soybeans $(2 \% \mathrm{DM})$, and a combination of the $2(1 \% \mathrm{DM}$ for each). In that study, VA and CLA were elevated a maximum of 3.7and 3.1-fold, respectively. Experienced panelists evaluated butter, pasteurized milk, and pasteurized milk with copper added. There were no differences in flavor scores for milks or butter, regardless of treatment or time of storage. In a separate report (Ramaswamy et al., 2001a), approximately 299 consumers were asked to evaluate the flavor and acceptability of control or FO milks and complete a questionnaire designed to determine the commercial viability of products made from FO milk. Consumers reported no off-flavors or difference in acceptability between the 2 milks, and indicated enthusiasm in purchasing dairy products with elevated CLA concentrations.

Avramis et al. (2003) used milk from cows fed supplemental fishmeal to produce milk with an altered fatty acid profile. Although the fatty acid composition of the milk was not given, the dairy cow ration was designed to alter the fatty acid composition and would be expected to elevate VA and CLA. An increase in the degree of fatty acid unsaturation, which would primarily be due to VA and CLA as well as some contribution from n-3 polyunsaturated fatty acids, was supported by physical measurements (lowering of butter oil dropping point, shift in melting profile) and observations (increase in churning time of cream to produce butter). The milk from the feeding trial was UHT pasteurized, standardized to $2 \%$ fat, and stored in the dark at $4{ }^{\circ} \mathrm{C}$. Expert graders evaluated the milk over the shelf life and detected no differences between the fish meal and control milks with regard to quality, flavor or, specifically, the presence of oxidized flavor. Similarly, a consumer panel did not detect a difference between the 2 milks as determined by triangle tests. Gonzalez et al. (2003), using fat obtained from the milk of cows fed high-oleic safflower oil or high-linoleic sunflower oil, evaluated the oxidation and quality of ice cream. Compared with control, VA and cis-9, trans-11 CLA were only elevated about $50 \%$ and there was no statistical effect of milk fat composition on the free fatty acid levels or acid values. The oxidative stability of the ice cream, as measured by peroxide value, was not statistically affected, although high values in the elevated VA/cis-9, trans-11 CLA ice cream were noted for some of the measurement periods during storage.

In contrast, a trained taste panel used by Lacasse et al. (2002) scored the flavor of $2.7 \%$ fat milk from cows fed protected (3\% DM) or unprotected FO $(3.7 \%$ DM) significantly lower than control and described it as unusual tasting (protected FO) or actively disliked (unprotected FO). An informal taste panel supported these results. The peroxide index was higher for the protected $\mathrm{FO}$ fed at $3 \% \mathrm{DM}$, giving further confirmation of oxidation. However, neither flavor scores nor peroxide index were adversely affected when milk from cows fed protected FO at a lower concentration (1.5\% DM) was evaluated. Similarly, at the concentrations of FO used by Baer et al. (2001; 2\% DM), Ramaswamy et al. ( $2001 \mathrm{~b} ; 1$ to $2 \% \mathrm{DM})$, and the present study ( $1 \%$ DM), FO did not impart detectable off-flavors. Maximum elevations of VA and cis-9, trans-11 CLA in the study by Lacasse et al. (2002) were 2.3- and 1.2-fold, respectively.

Most sensory research has used milk produced from cows receiving a diet designed to increase CLA rather than milk directly supplemented with CLA. Ruminant diets that increase CLA have other beneficial effects, such as concomitant increase in VA, and a decrease in saturated fatty acids. Direct fortification of milk, on the other hand, is prohibitively expensive and may not contain the same CLA isomers or isomer ratios as in milk fat. In the one study that used direct CLA supplementation (Campbell et al., 2003), 2\% fat milk was manufactured by adding cream or up to $2 \%$ CLA triglycerides directly to skim milk. The CLA was commercially produced and contained approximately equal amounts of cis-9, trans-11 CLA (36.9\%) and trans-10, cis-12 CLA (36.7 \%). Trained panelists participating in sensory evaluation of the milk noted a 
low intensity "grassy/vegetable" oil flavor compared with control milk. Consumer (untrained) evaluation indicated milk with CLA added was less acceptable than milk without CLA added.

\section{CONCLUSIONS}

Significant enhancement of the milk fat content of VA and cis-9, trans-11 CLA by 7.5- and 8-fold, respectively, was possible by combining feeding practices with targeted milk collection. The fatty acid composition of pasteurized, homogenized $2 \%$ fat milk from control and CLA diet groups was stable over a 14-d shelf life and there was no effect of light exposure. No flavor differences between the $2 \%$ fat pasteurized milks were detected over the commercial shelf life of the product. Similarly, sensory evaluation indicated the milks did not differ in susceptibility to the development of oxidized off-flavors. We conclude that it is possible to produce dairy products with a naturally enhanced content of VA and cis-9, trans-11 CLA (7.5and 8-fold increases, respectively) that have acceptable sensory characteristics.

\section{ACKNOWLEDGMENTS}

Authors gratefully acknowledge the assistance of M. Chapman, R. Kaltaler, L. Landolf, P. Wood, G. Birdsall, and members of the T\&R dairy staff, and the Milk Quality Improvement Program, which is funded by New York State Dairy Promotion Order. Partial funding was provided by Dairy Management Inc. (Rosemont, IL) and Hatch Regional Research Project W-181.

\section{REFERENCES}

Association of Official Analytical Chemists. 2000. Official Methods of Analysis. 17th ed. AOAC International, Gaithersburg, MD.

Avramis, C. A., H. Wang, B. W. McBride, T. C. Wright, and A. R. Hill. 2003. Physical and processing properties of milk, butter, and Cheddar cheeses from cows fed supplemental fish meal. J. Dairy Sci. 86:2568-2576.

Baer, R. J., J. Ryali, D. J. Schingoethe, K. M. Kasperson, D. C. Donovan, A. R. Hippen, and S. T. Franklin. 2001. Composition and properties of milk and butter from cows fed fish oil. J. Dairy Sci. 84:345-353.

Banni, S., S. D. Heys, and K. W. J. Wahle. 2003. Conjugated linoleic acids as anticancer nutrients: Studies in vivo and cellular mechanisms. Pages 267-282 in Advances in Conjugated Linoleic Acid Research, Vol. 2. J.-L. Sébédio, W. W. Christie, and R. Adlof, ed. AOCS Press, Champaign, IL.

Bauman, D. E., D. M. Barbano, D. A. Dwyer, and J. M. Griinari. 2000. Technical note: Production of butter with enhanced conjugated linoleic acid for use in biomedical studies with animal models. J. Dairy Sci. 83:2422-2425.

Bauman, D. E., B. A. Corl, and D. G. Peterson. 2003. The biology of conjugated linoleic acids in ruminants. Pages 146-173 in Advances in Conjugated Linoleic Acid Research, Vol. 2. J.-L. Sébédio, W. W. Christie, and R. Adlof, ed. AOCS Press, Champaign, IL.
Bauman, D. E., J. W. Perfield, and A. L. Lock. 2004. Effect of trans fatty acids on milk fat and their impact on human health. Pages 41-52 in Proc. Southwest Nutrition Conf., Tempe, AZ., Online. Available at: http://animal.cals.arizona.edu/swnmc/2004/proceedings.php.

Belury, M. A. 2002. Dietary conjugated linoleic acid in health: Physiological effects and mechanisms of action. Annu. Rev. Nutr. 22:505-531.

Campbell, W., M. A. Drake, and D. K. Larick. 2003. The impact of fortification on conjugated linoleic acid (CLA) on the quality of fluid milk. J. Dairy Sci. 86:43-51.

Chapman, K. W., L. J. Whited, and K. J. Boor. 2002. Sensory threshold of light-oxidized flavor defects in milk. J. Food Sci. 67:2770-2773.

Chouinard, P. Y., L. Corneau, W. R. Butler, Y. Chilliard, J. K. Drackley, and D. E. Bauman. 2001. Effect of dietary lipid source on conjugated linoleic acid concentrations in milk fat. J. Dairy Sci. 84:680-690.

Chouinard, P. Y., L. Corneau, A. Saebo, and D. E. Bauman. 1999. Milk yield and composition during abomasal infusion of conjugated linoleic acid. J. Dairy Sci. 82:2737-2745.

Christie, W. W. 1982. A simple procedure for rapid transmethylation of glycerolipids and cholesteryl esters. J. Lipid Res. 23:10721075.

Glantz, S. A., and B. K. Slinker. 2001. Primer of Applied Regression and Analysis of Variance. 2nd ed. McGraw-Hill Inc., New York, NY.

Gonzalez, S., S. E. Duncan, S. F. O'Keefe, S. S. Sumner, and J. H. Herbein. 2003. Oxidation and textural characteristics of butter and ice cream with modified fatty acid profiles. J. Dairy Sci. 86:70-77.

Hara, A., and N. S. Radin. 1978. Lipid extraction of tissues with a low-toxicity solvent. Anal. Biochem. 90:420-426.

International Dairy Foods Association. 2003. Page 80 in Dairy Facts. International Dairy Foods Association, Washington, DC.

Ip, C., M. Singh, H. J. Thompson, and J. A. Scimeca. 1994. Conjugated linoleic acid suppresses mammary carcinogenesis and proliferative activity of the mammary gland in the rat. Cancer Res. $54: 1212-1215$.

Kelsey, J. A., B. A. Corl, R. J. Collier, and D. E. Bauman. 2003. The effect of breed, parity, and stage of lactation on conjugated linoleic acid (CLA) in milk fat from dairy cows. J. Dairy Sci. 86:2588-2597.

Kritchevsky, D. 2003. Conjugated linoleic acids in experimental atherosclerosis. Pages 293-301 in Advances in Conjugated Linoleic Acid Research, Vol. 2. J.-L. Sébédio, W. W. Christie, and R. Adlof, ed. AOCS Press, Champaign, IL.

Lacasse, P., J. J. Kennelly, L. Delbecchi, and C. E. Ahnadi. 2002. Addition of protected and unprotected fish oil to diets for dairy cows. I. Effects on the yield, composition and taste of milk. J. Dairy Res. 69:511-520.

Lock, A. L., B. A. Corl, D. M. Barbano, D. E. Bauman, and C. Ip. 2004. The anticarcinogenic effect of trans-11 18:1 is dependent on its conversion to cis-9, trans-11 CLA by delta-9 desaturase in rats. J. Dairy Sci. 87:2698-2704.

Lock, A. L., and K. J. Shingfield. 2004. Optimising milk composition. Pages 107-188 in UK Dairying: Using science to meet consumers' needs. E. Kebreab, J. Mills, and D. Beever, ed. Nottingham University Press, Nottingham, UK.

Ma, Y., C. Ryan, D. M. Barbano, D. M. Galton, M. A. Rudan, and K. J. Boor. 2000. Effects of somatic cell count on quality and shelf-life of pasteurized fluid milk. J. Dairy Sci. 83:264-274.

Marshall, R. T. 1993. Standard Methods for Examination of Dairy Products, 16th ed. Am. Publ. Health Assoc., Inc., Washington, DC.

O’Mahony, M. 1986. Sensory Evaluation of Food. Marcel Dekker, Inc., New York, NY.

Parodi, P. W. 2003. Conjugated linoleic acid in food. Pages 101-122 in Advances in Conjugated Linoleic Acid Research, Vol. 2. J.-L. Sébédio, W. W. Christie, and R. Adlof, ed. AOCS Press, Champaign, IL. 
Parrish, F. C., Jr., B. R. Wiegand, D. C. Beitz, D. U. Ahn, M. Du, and A. H. Trenkle. 2003. Use of dietary CLA to improve composition and quality of animal-derived foods. Pages 189-217 in Advances in Conjugated Linoleic Acid Research, Vol. 2. J.-L. Sébédio, W. W. Christie, and R. Adlof, ed. AOCS Press, Champaign, IL.

Ramaswamy, N., R. J. Baer, D. J. Schingoethe, A. R. Hippen, K. M. Kasperson, and L. A. Whitlock. 2001a. Consumer evaluation of milk high in conjugated linoleic acid. J. Dairy Sci. 84:1607-1609.

Ramaswamy, N., R. J. Baer, D. J. Schingoethe, A. R. Hippen, K. M. Kasperson, and L. A. Whitlock. 2001b. Composition and flavor of milk and butter from cows fed fish oil, extruded soybeans, or their combination. J. Dairy Sci. 84:2144-2151.

Ritzenthaler, K. L., M. K. McGuire, R. Falen, T. D. Shultz, N. Dasgupta, and M. McGuire. 2001. Estimation of conjugated linoleic acid intake by written dietary assessment methodologies underestimates actual intake evaluated by food duplicate methodology. J. Nutr. 131:1548-1554.

Santos, M. V., Y. Ma, and D. M. Barbano. 2003. Effect of somatic cell count on proteolysis and lipolysis in pasteurized fluid milk during shelf-life storage. J. Dairy Sci. 86:2491-2503.
SAS Institute. 2001. SAS/STAT Users Guide (Release 8.0). SAS Inst., Inc., Cary, NC.

Shantha, N. C., L. N. Ram, J. O'Leary, C. L. Hicks, and E. A. Decker. 1995. Conjugated linoleic acid concentrations in dairy products as affected by processing and storage. J. Food Sci. 60:695-697.

Stanton, C., J. Murphy, E. McGrath, and R. Peterson. 2003. CLA in functional food: Enrichment of animal products. Pages 123145 in Advances in Conjugated Linoleic Acid Research, Volume 2. J.-L. Sébédio, W. W. Christie, and R. Adlof, ed. AOCS Press, Champaign, IL.

Toomey, S., H. Roche, D. Fitzgerald, and O. Belton. 2003. Regression of pre-established atherosclerosis in the apoE(-/-) mouse by conjugated linoleic acid. Biochem. Soc. Trans. 31:1075-1079.

Turpeinen, A., M. Mutanen, A. Aro, I. Salminen, S. Basu, D. Palmquist, and J. M. Griinari. 2002. Bioconversion of vaccenic acid to conjugated linoleic acid in humans. Am. J. Clin. Nutr. 76:504-510.

Watkins, B. A., and Y. Li. 2003. CLA in functional food: Enrichment of animal products. Pages 174-188 in Advances in Conjugated Linoleic Acid Research, Vol. 2. J.-L. Sébédio, W. W. Christie, and R. Adlof, ed. AOCS Press, Champaign, IL. 